\title{
DO PROFIT-SHARING RATE, PROMOTION MEDIA, LOCATION, AND SERVICE FACILITIES AFFECT MUSLIM DECISIONS TO USE ISLAMIC BANKS?
}

\author{
Nur Rizqi Febriandika \\ Universitas Muhammadiyah Surakarta, Indonesia \\ rizqi.febriandika@ums.ac.id
}

https://doi.org/10.46367/iqtishaduna.v10i2.414

Received: Oct 14, 2021 Revised: Nov 15, 2021 Accepted: Nov 24, 2021 Published: Des 17, 2021

\begin{abstract}
The majority of Indonesian people are Muslim, making Indonesia a potential market in the development of Islamic banking. The purpose of this study was to determine whether profit-sharing rate, promotion media, location, service facilities affect the decisions of the Muslim community to use Islamic banks. This type of research is quantitative research, which uses the method of structural equity modelling (SEM). The large sample size for the SEM method is based on the number of indicators in the variable due to the enormous population size, namely Muslims in Indonesia. The number of respondents in this study was 214 people. The results of this study indicate that profit-sharing rate, promotion media, location, service facilities do not affect the decisions of the Muslim community to use Islamic banks. Muslims are more likely to choose Islamic banks because of the halal label than other factors. Factors that generally make customers use conventional banks do not apply to Islamic banks. This research can be a reference or a reference for Islamic banks in making policies. Variables that are proven to have no effect can be eliminated in making policies to increase Islamic bank customers.
\end{abstract}

Keywords: Profit-Sharing Rate, Promotion Media, Location, Service Facilities, Muslim Decisions.

\section{INTRODUCTION}

Indonesia is a country with the largest Muslim population. The majority of Muslim people make Indonesia a potential market in the development of Islamic finance (Febriandika, Millatina, Luthfiyatillah, and Herianingrum 2020). The market share of Islamic banks in Indonesia is still tiny, around 6.51 percent. They consider that Islamic banking in Indonesia has been operating for more than 20 years and is still far behind compared to other countries. Malaysia has achieved a market share of 29 percent, Brunei 57 percent, Kuwait 49 percent, Qatar 27 percent, Saudi Arabia 65 percent, and the United Arab Emirates 24 percent (Pebrianto 2021). This phenomenon shows that many Muslims do not use Islamic banks and tend to choose conventional banking. Some many conditions and variables make Muslims not use Islamic banks.

Even though most Indonesian people are Muslim, there are still many who choose conventional banks over Islamic banks (Haida, Pratama, Sukarnoto, and 
Widiawati 2021). This makes the market share of Islamic banks lower than conventional banks. Muslim customers continue to save and use conventional bank services. Therefore, as a country with the most significant Muslim majority globally, it should have much better potential than the current condition (Tripuspitorini 2020). Many studies have tried to answer this problem with a variety of different approaches. Aisy and Mawardi (2016) tried to solve this problem by using a Islamic bank asset growth with macroeconomic variables such as inflation, GDP Growth, BI rate, and money supply and internal variables such as profit-sharing rate and promotion education and training cost, NPF ratio, ROA ratio, FDR ratio, Third-Party Funds, the quantity of bank office, and office channeling. This has not answered the real problem, namely the lack of Muslims in using Islamic banking. Therefore, it is necessary to research with costumers (respondents) approach to explore what variables make them use Islamic banks. This has been attempted by Andespa (2017) related to what factors make Muslims save in Islamic banks. The focus of this research is limited to one Islamic bank product, namely saving in Islamic banks, and does not cover all other Islamic bank products.

This study uses variables with a customer approach, precisely what factors can influence people's decisions to use Islamic banks. Because apart from Islamic banks, there are also conventional banks. This study explicitly uses the variables of the profit-sharing rate, promotion, location, and service facilities as factors that influence Muslim decisions to use Islamic banks to distinguish it from previous research, both in terms of variables and indicators used. According to Kotler and Keller (2017), sales promotion, as the main element in a marketing campaign, is a collection of incentive tools, mostly short-term, designed to stimulate consumers' faster or more excellent purchase of specific products or services consumers or traders.

Profit-sharing is a profit-sharing system between investors and managers of operating profit-sharing funds. Profit-sharing is that apart from not violating Islamic law, it can also benefit both parties through the agreed contract (Wasilah and Nurhayati 2013). Location is one of the factors that affect the Muslim community due to the location that is easily accessible by vehicles and the condition of the building, building maintenance to make the Muslim community comfortable in Islamic banks. For the banking world, the choice of location must prioritize economic principles, where the existence of the location of an Islamic bank must be able to provide convenience for customers to access the Islamic bank. The closer the location of the Islamic bank to the Muslim community will affect the decisions of the Muslim community to visit the Islamic bank (Oktaviani 2018). Therefore, this study aims to show the effect of the profit-sharing rate, promotion, location, and service facilities on the decisions of Muslims to use Islamic banks.

\section{LITERATURE REVIEW}

\section{Islamic Banks}

Islamic banks run their operations with Islamic principles, which is contained in Law Number 10 of 1998 concerning Banking. Article 1, number 13 of the law explains that Islamic principles are the rules of agreements based on 
Islamic law between banks and other parties to save funds or finance business activities or other activities that are declared following Islamic principles. Its activities include financing based on the principle of profit-sharing (mudharabah), financing based on the principle of equity participation (musyarakah), the principle of buying and selling (murabahah), and so on (Kasmir 2018).

Islamic banks are financial institutions that facilitate economic mechanisms, especially in the real sector (Yudiana 2014). Islamic banking is a bank whose operating system does not use interest but uses a profit-sharing system. Islamic banking is a banking institution whose operational procedures and products are developed based on the Qur'an and the Hadith of the Prophet Muhammad SAW (Wilardjo 2005). Islamic banks have three main functions: collecting funds from the public, channeling funds to the public, and providing services in the form of Islamic banking services (Nurdin and Yusuf 2020).

The purpose of Islamic banks is to provide financial facilities by seeking financial instruments that are commensurate with the provisions and norms of Islamic. There are various kinds of products offered by Islamic banks, one of the products offered by Islamic banks are current accounts, savings, and deposits (Aziz 2019). Saving is an action recommended by Islam because saving means a Muslim prepares himself for the implementation of future planning and to face things that are not desirable (Antonio 2011). Saving is broadly defined as an activity set aside from income to be collected as reserves in the future. According to Aziz (2019), Islamic banks implement two savings contracts, namely wadi'ah and mudharabah.

\section{Profit-Sharing Rate}

Profit-sharing in Islamic banking is a unique feature offered to the public. In Islamic rules relating to the distribution of business results, it must be determined in advance at the beginning of the contract (Kartika, Jubaedah, and Astuti 2020). Nurhayati and Wasilah (2015) said that the principle of profitsharing is the rule that is used as the basis for the distribution of operating results is gross profit, not total revenue (turnover). According to Karim (2008), Islamic banks will distribute the proceeds to the owners of the funds following the agreed ratio. According to Wahab (2016) that the profit-sharing calculation mechanism applied to Islamic banking consists of two systems, namely Profit Sharing and Revenue Sharing. Research conducted by Wahab (2016) shows that the level of profit-sharing has a significant relationship to people's interest in saving in Islamic banks. Meanwhile, according to another study, Prihanto (2017), profit sharing has been shown to have a positive and significant influence on people's decisions in choosing to save in Islamic banks. Based on the existing theory and research results, the first hypothesis can be formed as follows:

$\mathrm{H}_{1}$ : profit-sharing rate affects the decisions of Muslims to use Islamic banks.

\section{Location}

Location is where the company operates or where the company carries out activities to produce goods and services concerned with the economic aspect (Tjitono 2009). A banking location is a network where customers can take advantage of banking products and services, so bank location can be interpreted as a strategy from banking to attract customer interest (Wahjono 2010). In 
determining the location of branch offices, banks must consider several aspects not to harm customers and banks. Bank location is where bank branch products are traded, and banking control centers are traded (Fajriyah 2013). Careful considerations in determining the location include the following indicators: (1) Access, for example, a location that is easily accessible by public transportation; (2) Environment, namely the surrounding area that supports the services offered; (3) Visibility, for example, the location can be seen clearly from the side of the road; (4) Traffic, the number of people passing by can lead to impulse buying and traffic congestion and congestion can also be an obstacle (Tjiptono 2009). According to Andespa's research (2018), location influences people's interest in saving in Islamic banks because most people will usually choose the location closest to their homes to use a financing service. Based on the existing theory and research results, the first hypothesis can be formed as follows:

$\mathrm{H}_{2}$ : location affects the decisions of Muslims to use Islamic banks.

\section{Promotion}

Promotion is one of the keys to the company's success. In marketing, promotion is a communication activity carried out by a person or company to the broader community (Akhmetshin, Ilyasov, Sverdlikova, Tagibova, Tolmachev, and Yumashev 2018). The goal is to introduce the product to the public and influence them to buy and use it (Akhmetshin, Ilyasov, Sverdlikova, Tagibova, Tolmachev, and Yumashev 2018). According to Rismawati, Wahyuni, and Widodo (2019), promotion is a marketing strategy carried out by banks to customers to explain bank products so that customers get precise information about the products offered by the bank and customers to choose the appropriate product.

The forms of promotion can be print media such as newspapers, electronic media (such as television), and information can also be conveyed via the internet (Febriandika, Millatina, Luthfiyatillah, and Herianingrum 2020). The promotion reflects activities that communicate the advantages of the product and persuade consumers to buy it. So, this promotion is a component used to provide and influence the company's products. The activities included in the promotion are advertising, sales promotion, personal selling, and publicity (Febriandika, Millatina, Luthfiyatillah, and Herianingrum 2020).

The marketing mix consists of everything a company can do to influence the demand for its products. The many possibilities can be grouped into four variables known as the 4Ps: product, price, place, and promotion (Heckman and Moktan 2020). Direct marketing or also known as personal selling. Personal selling is an oral presentation in a conversation with a prospective buyer aimed at achieving a sale. There is a direct, face-to-face interaction between buyers and sellers (Heckman and Moktan 2020).

According to research conducted by Firman (2018), promotional media affects people's interest in saving in Islamic banks because most people will be interested in a financing service when they see promotions on the internet billboards and other conventional promotional media. This is also supported by research conducted by Pradesyah (2020), which says that promotion affects a public interest in conducting transactions at Islamic banks by 4.32 percent. Based 
on the existing theory and research results, the first hypothesis can be formed as follows:

$\mathrm{H}_{3}$ : promotion media affects the decisions of Muslims to use Islamic banks.

\section{Service Facilities}

The definition of service is all actions taken by one party to another, which are tangible and do not result in ownership of something, and the product is not always physically related (Kotler and Keller 2017). The basics of service need to be mastered by customer service before carrying out their duties because there are many diverse customer characters (Kasmir 2018). Indicators of service facilities, namely: (1) Reliability: the ability to provide the promised service promptly, accurately, and satisfactorily; (2) Responsiveness: responsiveness of staff to provide services and help customers; (3) Assurance: assurance, covering the knowledge, competence, courtesy, and trustworthiness of the staff; (4) Empathy: ease in establishing relationships, good communication, personal attention and understanding of the individual needs of customers; (5) Tangibles: physical facilities, equipment, employees and means of communication (Kasmir 2018).

According to research conducted by Cahyani, Saryadi, and Nurseto (2013), service quality had a significant effect on interest in saving at BNI Syariah Banks in Semarang City, namely 47.2 percent. Supported by research conducted by Pradesyah (2020), service facilities affect people's interest in saving in Islamic banks because if the service is not good, then the financing service will not demand the public. Based on the existing theory and research results, the first hypothesis can be formed as follows:

$\mathrm{H}_{4}$ : service facilities affect the decisions of Muslims to use Islamic banks.

\section{METHODS}

This research uses a quantitative research approach. A standardized, selfadministered questionnaire was developed from an extensive literature review. All variables used in this study were adopted from previous studies. Constructs in the proposed model were evaluated by using multiple-item measures. This research uses the SEM data analysis technique, which is operated using Amos and SPSS. The use of SEM is because SEM is considered more accurate.

Sources of data in this study, the authors use primary data sources. Primary data is data generated directly to meet the needs of the research being handled by Malhotra (2010). The data comes from a survey in the form of a structured questionnaire. The questionnaire will be filled out using a selfadministered questionnaire technique, which the respondent himself fills out. Data collection was carried out through survey techniques using online questionnaires, namely through google forms, to respondents. This study used a sample selected from the sampling technique and used the SEM analysis technique.

According to Sholihin and Ratmono (2021), some guidelines for determining sample size for SEM are given as follows: (1) If the parameters used are using the method, the maximum (maximum likelihood estimation) recommended sample size is between 100 to 200, and the minimum sample is 50 . (2) A total of 5 to 10 times the number of parameters in the model. (3) Equal to 5 to 10 times the sum of the total latent variables (indicator variables). 
This study uses 25 indicators; thus, Hair, Gabriel, and Patel (2014) required a minimum sample of $5 \times 25$ or 125 respondents. In this study, the number of respondents obtained was 214, which already met the requirements. EFA (Exploratory Factor Analysis) and CFA (Confirmatory Factor Analysis) methods are used to ensure that the data is valid and reliable (Febriandika, Anam, and Purti 2020).

\section{RESULTS AND DISCUSSION}

\section{Demographic Characteristics}

Table 1. Demographic Characteristics

\begin{tabular}{|c|c|c|}
\hline \multicolumn{3}{|l|}{ Gender } \\
\hline & Amount & Percentage \\
\hline Male & 96 & 44.9 \\
\hline Female & 118 & 55.1 \\
\hline \multicolumn{3}{|l|}{ Age } \\
\hline $18-24$ years & 164 & 76.6 \\
\hline 25-34 years & 42 & 19.6 \\
\hline $35-44$ years & 4 & 1.9 \\
\hline $45-54$ years & 4 & 1.9 \\
\hline \multicolumn{3}{|c|}{$\begin{array}{l}\text { Last Education } \\
\end{array}$} \\
\hline Bachelor & 66 & 30.8 \\
\hline Senior High School & 142 & 66.3 \\
\hline Junior High School & 6 & 2.9 \\
\hline \multicolumn{3}{|l|}{ Job } \\
\hline BUMN & 3 & 1.5 \\
\hline Housewife & 4 & 1.9 \\
\hline Private Employee & 63 & 29.4 \\
\hline Student & 90 & 42.1 \\
\hline Civil Servants & 3 & 1.5 \\
\hline Entrepreneur & 51 & 23.9 \\
\hline \multicolumn{3}{|l|}{ Salary } \\
\hline$<$ IDR 500,000 & 38 & 17.8 \\
\hline IDR 500,000 - IDR $1,000,000$ & 40 & 18.7 \\
\hline IDR $1,000,000$ - IDR $1,500,000$ & 23 & 10.8 \\
\hline IDR $1,500,000$ - IDR 2,000,000 & 30 & 14.0 \\
\hline$>$ IDR 2,000,000 & 83 & 38.8 \\
\hline
\end{tabular}

Source: primary data (processed)

Table 1 shows the characteristics of respondents, namely religion, gender, age, last education, occupation, and income. It can be concluded that the number of people who use Islamic banks is dominated by women as many as 118 , having an age range of 18-34 years as many as 206 respondents, the latest education level of the majority of respondents is Senior High School level totaling 142 while Bachelor level with a total of 66 respondents. The work is dominated by students as many as 90 respondents. As for the monthly income of 214 respondents, most of their salary is more than IDR 2,000,000 (38.8 percent). 
Validity and Reliability Test

Table 2. Exploratory Factor Analysis Results

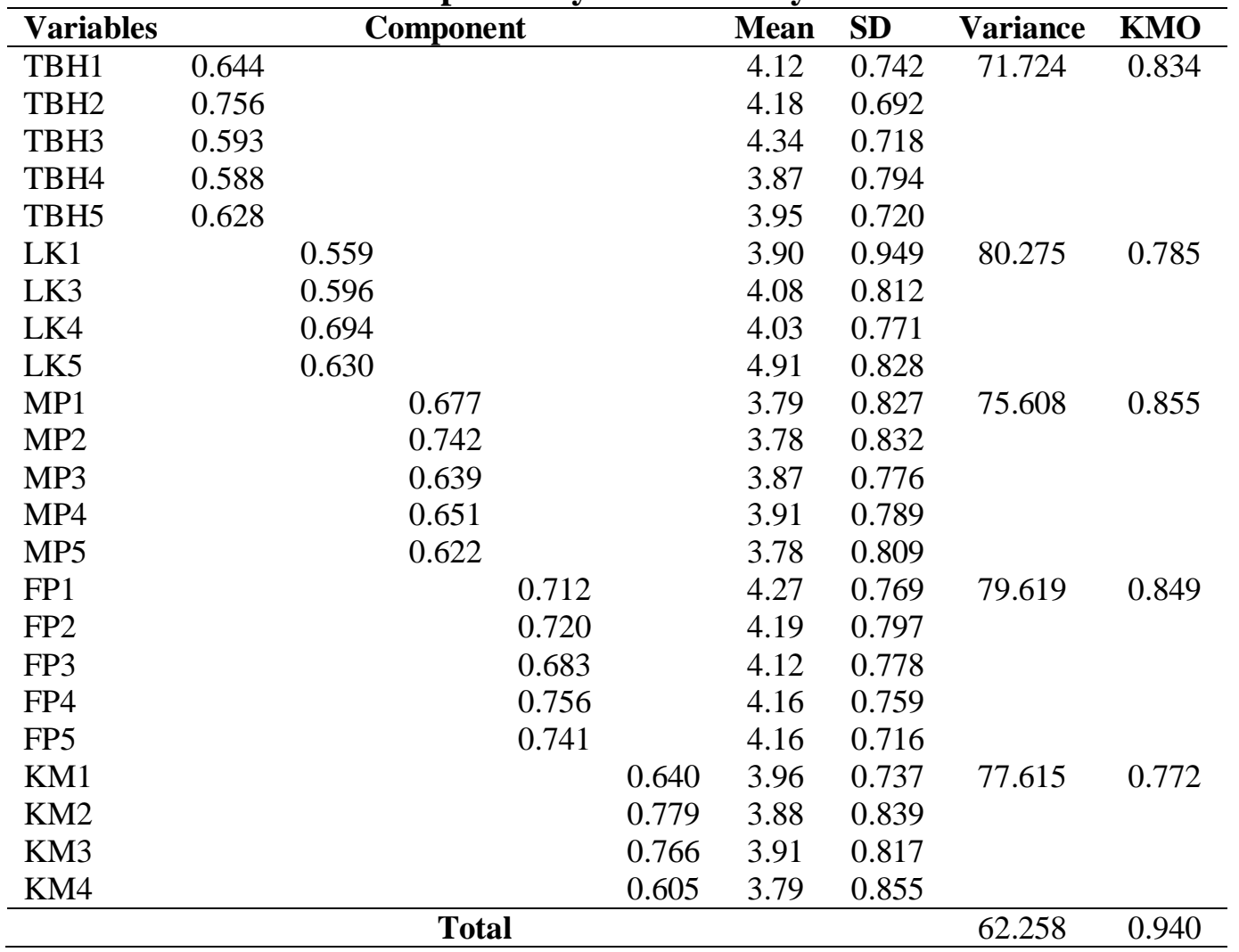

Note: TBH is profit sharing rate; LK is the location; MP is promotion media; FP is a service facility; KM is the decisions of Muslim; SD is standard deviation; KMO is kaiser-meyer-olkin.

Source: primary data (processed)

The KMO results for each variable showed promising results, which were 0.940 (above 0.5). This means that the factor is sufficient that the data taken can be factored in, with a p-value $=0.00$, and the total extraction variance is 62.258 percent. Table 2 shows the results of the detailed EFA analysis consisting of components, average, SD, explaining the extracted variation, KMO for each variable item, and the total KMO and variance extracted for all variable items.

Reliability test aims to measure a questionnaire which is an indicator of a variable or constructs. A questionnaire is said to be reliable or reliable if a person's answer to the statement is consistent or stable over time. This study uses the cronbach's alpha method. For consideration, cronbach's alpha was: $>0.9$ very good, $>0.8$ good, $>0.7$ acceptable, $>0.6$ questionable, $>0.5$ poor, and $<0.5$ unacceptable.

Table 3 shows cronbach's alpha coefficient for all questionnaire items with alpha $=0.945$. Furthermore, the reliability test is carried out separately on each variable to determine the reliability of each independent variable. Table 3 shows that the cronbach's alpha has shown by each variable also reaches good to excellent values, ranging from 0.804 to 0.883 , and is declared reliable. 
Table 3. Construct Reliability

\begin{tabular}{ccc}
\hline Variable & Cronbach's Alpha & Number of Item \\
\hline TBH & 0.817 & 5 \\
LK & 0.810 & 4 \\
MP & 0.861 & 5 \\
FP & 0.883 & 5 \\
KM & 0.804 & 4 \\
\hline Total & $\mathbf{0 . 9 4 5}$ & $\mathbf{2 3}$ \\
\hline
\end{tabular}

Source: primary data (processed)

The measure model process is a process of the CFA test, namely confirmatory factor analysis. CFA serves to identify indicators that are constructs of research variables or, in other words, these indicators are one unit or have unidimensionality. CFA test was performed on each variable. The results of the CFA test are shown in Figure 1.

Figure 1. Confirmatory Factor Analysis (CFA) Result

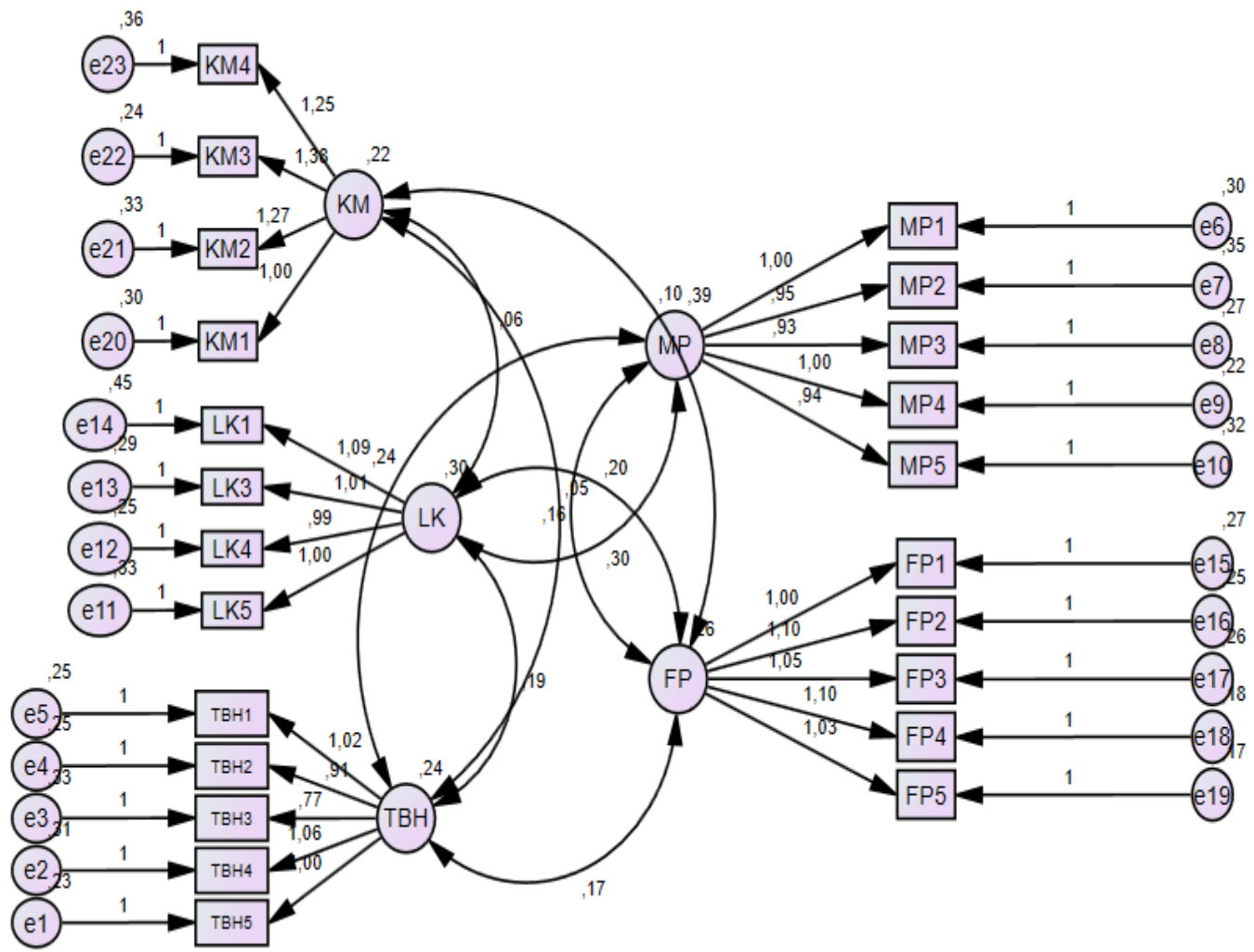

Source: primary data (processed)

The results of the estimation of the measurement model or the initial means of the model on all variables (Figure 1) using the Maximum likelihood method produced by AMOS are shown in Table 4, showing that all goodness of fit criteria includes chi-square, degree of freedom (df), GFI, CFI, TLI, RMSEA. This shows that the suitability index for each variable exceeds the limit of the recommended value, so it can be said to be in the fit model category. 
Table 4. CFA Goodness of Fit

\begin{tabular}{cccc}
\hline GOF Index & $\begin{array}{c}\text { Acceptable } \\
\text { Value }\end{array}$ & CFA Model & Description \\
\hline $\mathrm{X}^{2}$ (Chi-square) & & 524,864 & Good Fit \\
df (Degree of & & 221 & \\
freedom) & & & \\
$\mathrm{X}^{2} / \mathrm{df}$ & $<3$ & 2,37 & Good Fit \\
GFI & $>0.8$ & .850 & Good Fit \\
CFI & $>0.9$ & .917 & Good Fit \\
TLI & $>0.9$ & .904 & Good Fit \\
RMSEA & $<0.08$ & 0.068 & Good Fit \\
\hline Source: primary data (processed) & &
\end{tabular}

\section{Hypothesis Test}

Table 5. Hypothesis Testing Results

\begin{tabular}{cccccc}
\hline Hypothesis & Path & B & S.E & P-value & Results \\
\hline $\mathrm{H}_{1}$ & $\mathrm{TBH} \rightarrow \mathrm{KM}$ & -0.050 & 0.200 & 0.822 & Not significant \\
$\mathrm{H}_{2}$ & $\mathrm{LK} \rightarrow \mathrm{KM}$ & -0.021 & 0.307 & 0.956 & Not significant \\
$\mathrm{H}_{3}$ & $\mathrm{MP} \rightarrow \mathrm{KM}$ & 0.562 & 0.310 & 0.175 & Not significant \\
$\mathrm{H}_{4}$ & $\mathrm{FP} \rightarrow \mathrm{KM}$ & 0.326 & 0.163 & 0.082 & Not significant \\
\hline
\end{tabular}

Source: primary data (processed)

The hypothesis is accepted if the probability value ( $\mathrm{p}$-value) is $<0.05$, meaning a significant influence between the independent and dependent variables. Conversely, the hypothesis is rejected if the probability value ( $\mathrm{p}$-value) $>0.05$, meaning no significant effect exists between the independent variables and the dependent variable. Table 5 shows that the $\mathrm{H}_{1}$ hypothesis has a p-value of $0.822>$ 0.05 , so $\mathrm{H}_{1}$ is rejected, meaning that profit-sharing rate does not affect Muslim decisions. Hypothesis $\mathrm{H}_{2}$ has a p-value of $0.956>0.05$, so $\mathrm{H} 2$ is rejected, meaning that location does not affect Muslim decisions. Hypothesis $\mathrm{H}_{3}$ has a $\mathrm{p}$ value of $0.175>0.05$, so $\mathrm{H}_{3}$ is rejected, meaning that promotional media does not affect Muslim decisions. Hypothesis $\mathrm{H}_{4}$ has a p-value of $0.082>0.05$, so $\mathrm{H}_{4}$ is rejected, meaning that service facilities do not affect Muslim decisions.

\section{Profit-Sharing Rate on Muslim Decisions to Use Islamic Banks}

The results of this study indicate that profit-sharing rate does not affect Muslim decisions in using Islamic banks. This is in line with the findings by Wahab (2016), which states that profit-sharing rate is not the main factor in a person's decisions to become a customer in an Islamic bank. This happens because profit-sharing is not dominant in encouraging people to save in Islamic banks. Then the results of this study are also supported by research conducted by Syahputra (2017), which states that profit-sharing and interest rates have no significant effect on savings in Islamic banks, meaning that religious factors are still a driving force for customers to save in Islamic banks. The results of this study are contrary to research conducted by Prihanto (2017) which states that profit-sharing has proven to have a positive and significant effect on people's decisions in choosing to save in Islamic banks. 


\section{Location on Muslim Decisions to Use Islamic Banks}

The results of this study indicate that location does not affect Muslim decisions in using Islamic banks. This indicates that customers are not concerned with the location of the bank when saving in Islamic banks. The results of this study support the research conducted by Sriwahyuni (2019), which states that location negatively affects people's decisions to save in Islamic banks. This means that there is an opposite relationship between the location and the decisions of the Muslim community to save; if the location of the Islamic bank is not strategic, the public's decisions to save at the Islamic bank increases. Another opinion is supported by Harahap (2018), which states that location negatively affects decisions to save in Islamic banks. The results of this study contradict the findings of Andespa (2018), which states that location affects people's interest in saving in Islamic banks because most people will usually choose the location closest to their place of residence to use financing services.

\section{Media Promotion on Muslim Decisions to Use Islamic Banks}

This study indicates that promotional media does not affect Muslim decisions in using Islamic banks. This indicates that customers are not affected by various kinds of promotional media carried out by Islamic banks, so customers want to save in Islamic banks. According to Kotler and Keller (2017), sales promotion is a significant element in marketing, designed to stimulate consumers to use products or services. However, this was not proven in this study. The results of this study are in line with the findings of Untoro (2020), which states that promotion does not affect people's interest in saving at Islamic banks in Tangerang Raya, so it can be interpreted that not all promotions carried out by Islamic banks affect people's decisions saving in the Islamic bank itself. However, the results of this study contradict the research conducted by Firman (2018); Pradesyah (2020), which states that promotional or promotional media affect people's interest in saving in Islamic banks.

\section{Service Facilities on Muslim Decisions to Use Islamic Banks}

The results of this study indicate that service facilities do not affect Muslim decisions in using Islamic banks. This indicates that customers feel that the service facilities provided by Islamic banks do not affect their decisions to use Islamic banks. Kasmir's (2018) statement supports this that the character of customers is very diverse in receiving services provided by a company. The results of this study contradict Syarif's (2019) findings, which states that service quality has a significant effect on saving decisions. Then the results of this study also contradict the findings by Cahyani, Saryadi, and Nurseto (2013); Pradesyah (2020), which states that service quality has a significant effect on interest in saving in Islamic banks.

Customers prioritizing profits or benefits derived from service quality is a factor that can influence customer interest (Indi 2019). If the service they receive is wrong, they will not want to make transactions at the financial institution. On the other hand, if the service is good, they will not hesitate to be loyal to the financial institution. Muslims tend to choose Islamic banks because of the halal label over other factors. Factors that generally make customers use conventional banks do not apply to Islamic banks. 
Muslims tend to choose Islamic banks because of the halal label over other factors. Factors that generally make customers use conventional banks do not apply to Islamic banks. Based on the results of the estimation and analysis in this study, the implications that can be given are that it is expected to be a reference or reference for Islamic banks in attracting customers. The variables studied do not affect the decisions of Muslim customers in using Islamic banks. Therefore, making other models using other variables that can attract customers' interest in using Islamic banks is necessary. It is hoped that further research can expand the types of variables used and use a complex model because the model used in this study is still simple ( $\mathrm{x}$ and $\mathrm{y}$ ) without any intermediate variables (variable $\mathrm{z}$ ). In general, an Islamic bank seeks to satisfy customers in using the banking products it produces. Hence, banks need to know or understand customer behavior, especially those targeted by banks, even though today's customers are very selective and have sufficient knowledge of a service (Andespa 2017). They are cautious in choosing, considering buying a product or service. For this reason, understanding consumer behavior is very influential on the company's marketing strategy following the products or services offered (Febriandika and Hakimi 2020).

\section{CONCLUSION}

The results of this study indicate that profit-sharing rate, promotion media, location, service facilities do not affect the decisions of the Muslim community to use Islamic banks. Muslims tend to choose Islamic banks because of the halal label over other factors. Factors that generally make customers use conventional banks do not apply to Islamic banks. This research is expected to be a reference for Islamic banks.

In addition, from the side of many people who are not familiar with Islamic banks, people will know and know Islamic banks more deeply if the service and promotion facilities are carried out as attractively as possible so that people know more about Islamic banks and attract people's decisions to save in Islamic Banks. This is done because people who only know about Islamic banks do not understand what systems exist.

Muslims tend to choose Islamic banks because of the halal label over other factors. Factors that generally make customers use conventional banks do not apply to Islamic banks. Based on the results of the estimation and analysis in this study, the implications that can be given are that it is expected to be a reference or reference for Islamic banks in attracting customers. The variables studied do not affect the decisions of Muslim customers in using Islamic banks. Therefore, making other models using other variables that can attract customers' interest in using Islamic banks is necessary. It is hoped that further research can expand the types of variables used and use a complex model because the model used in this study is still simple ( $\mathrm{x}$ and $\mathrm{y}$ ) without any intermediate variables (variable $\mathrm{z}$ ). 


\section{REFERENCES}

Aisy, Diamantin Rohadatul and Imron Mawardi. 2016. "Faktor-Faktor Yang Mempengaruhi Pertumbuhan Aset Bank Syariah di Indonesia Tahun 20062015." Jurnal Ekonomi Syariah Teori dan Terapan, 3(3): 246-265. http://dx.doi.org/10.20473/vol3iss20163pp249-265.

Akhmetshin, Elvir Munirovich, R. H. Ilyasov, E. A. Sverdlikova, A. A. Tagibova, A. V. Tolmachev, and Alexei Valerievich Yumashev. 2018. "Promotion In Emerging Markets." European Research Studies, 21(SI2): 652-665. https://econpapers.repec.org/article/ersjournl/v_3axxi_3ay_3a2018_3ai_3a special2_3ap_3a652-665.htm.

Andespa, Roni. 2017. "Faktor-Faktor Yang Mempengaruhi Minat Nasabah Dalam Menabung Di Bank Syariah." AL-MASRAF: Jurnal Lembaga Keuangan dan Perbankan, 2(1): 43-57. http://journal.febi.uinib.ac.id/index.php/almasraf/article/view/90.

Andespa, Roni. 2018. "Pengaruh Atribut Produk Terhadap Minat Menabung Nasabah Di Bank Syariah". Maqdis: Jurnal Kajian Ekonomi Islam 3 (2): 181-190. https://journal.febi.uinib.ac.id/index.php/maqdis/article/view/190

Antonio, Muhammad Syafii. 2011. Bank Syariah: Dari Teori Ke Praktik. Gema Insani.

Aziz, Muh. Abdul. 2019. Analisis Faktor-Faktor Yang Mempengaruhi Minat Menabung Di Bank Syariah (Studi Kasus Pada Remaja Masjid di Kecamatan Getasan Kabupaten Semarang). Skripsi Institut Agama Islam Negeri (IAIN) Salatiga. http://e-repository.perpus.iainsalatiga.ac.id/5337/.

Cahyani, Asih Fitri, Saryadi Saryadi, and Sendhang Nurseto. 2013. "Pengaruh Persepsi Bunga Bank Dan Kualitas Pelayanan Terhadap Minat Menabung Pada Bank BNI Syariah Di Kota Semarang." Jurnal Ilmu Administrasi Bisnis, 2(3): 371-379. https://ejournal3.undip.ac.id/index.php/jiab/article/view/3120.

Fajriyah, Neneng. 2013. Pengaruh Promosi, Reputasi, dan Lokasi Strategis terhadap Keputusan Nasabah Menggunakan Produk Tabungan Haji Bank Mandiri KCP Tangerang Bintaro Sektor III. Skripsi UIN Syarif Hidayatullah Jakarta. https://repository.uinjkt.ac.id/dspace/handle/123456789/23879.

Febriandika, Nur Rizqi and Fifi Hakimi. 2020. "Analisis Kesesuaian Syariah Electronic Money Pada Bank Penerbit Uang Elektronik Di Indonesia." AnNisbah: Jurnal Ekonomi Syariah,7(1): 213-249. http://ejournal.iaintulungagung.ac.id/index.php/nisbah/article/view/2183.

Febriandika, Nur Rizqi, Syaiful Anam, and Ananda Syahdini Emilia Putri. 2020. "The Effect of Distributive Justice, Procedural Justice of Compensation and Emotional Intelligence on Affective Commitments." Jurnal Ilmiah $\begin{array}{llll}\text { Ekonomi Islam } & \text { (JIEI), } 6 & \text { (1): }\end{array}$ http://dx.doi.org/10.29040/jiei.v6i1.654.

Febriandika, Nur Rizqi, Afifah Nur Millatina, Luthfiyatillah Luthfiyatillah, and Sri Herianingrum. 2020. "Customer E-Loyalty of Muslim Millennials in Indonesia: Integrated Model of Trust, User Experience and Branding in ECommerce Webstore." IC4E 2020: Proceedings of the 2020 11th 
International Conference on E-Education, E-Business, E-Management, and E-Learning, 369-376. https://doi.org/10.1145/3377571.3377638.

Firman, Rachmad Nor. 2018. "Pengaruh Media Promosi Perbankan Syariah Terhadap Minat Menabung Masyarakat di Bank Syariah Mandiri Pasuruan." Tarbawi: Jurnal Studi Pendidikan Islami, 5(1): 1-9. http://ejournal.kopertais4.or.id/tapalkuda/index.php/tarbawi/article/view/3 097.

Haida, Nur, Gama Pratama, Toto Sukarnoto, and Widiawati Widiawati. 2021. "Pengaruh Pemahaman Masyarakat Tentang Riba Terhadap Minat Bertransaksi Di Bank Syariah." Ecobankers: Journal of Economy and Banking, 2(2):

131-139. http://www.journal.bungabangsacirebon.ac.id/index.php/EcoBankers/articl e/view/484.

Hair, Joseph F., Marcelo Gabriel and Vijay Patel. 2014. "AMOS CovarianceBased Structural Equation Modeling (CB-SEM): Guidelines on Its Application as a Marketing Research Tool." Brazilian Journal of Marketing, 13(2). https://ssrn.com/abstract=2676480.

Harahap, Zakaria. 2018. "Pengaruh Produk Dan Lokasi Terhadap Keputusan Nasabah Menabung di Bank Sumsel Babel Cabang Prabumulih Unit Layanan Syariah.” I-FINANCE: a Research Journal on Islamic Finance, 4(1): 102-120. https://doi.org/10.19109/ifinance.v4i1.2305

Heckman, James J. and Sidharth Moktan. 2020. "Publishing And Promotion In Economics: The Tyranny Of The Top Five." Journal of Economic Literature 58 (2): 419-70. https://doi.org/10.1257/jel.20191574.

Indi, Irnawati. 2019. Faktor-Faktor Yang Memengaruhi Minat Masyarakat Menabung Di Bank Syariah (Studi Kasus Pada Masyarakat Di Kecamatan Rappocini Kota Makassar. Skripsi Universitas Negeri Makassar. http://eprints.unm.ac.id/15043/.

Karim, Adiwarman A. 2008. Bank Islam: Analisis Fiqih dan Keuangan Edisi 3. Jakarta: PT. Raja Grafindo Persada.

Kartika, Rika, Siti Jubaedah, and Apri Dwi Astuti. 2020. "The Influence of Financing to Deposit Ratio, Return on Assets and Non Performing Finance on Profit Sharing Finance of Sharia Banks in Indonesia." In 1st International Conference on Accounting, Management and Entrepreneurship (ICAMER 2019), Advances in Economics, Business and Management Research, 123: 136-140. https://www.atlantispress.com/article/125936184.pdf.

Kasmir, Kasmir. 2018. Dasar-Dasar Perbankan. Jakarta: PT Raja Grafindo Persada.

Kotler, Philip and Kevin Lane Keller. 2017. Manajemen Pemasaran. Klaten: PT Macananjaya Cemerlang.

Malhotra, Naresh K. 2010. Riset Pemasaran Pendekatan Terapan. Jakarta: PT. Indeks.

Nurdin, Nurdin and Khaeruddin Yusuf. 2020. "Knowledge Management Lifecycle In Islamic Bank: The Case Of Syariah Banks In Indonesia." International Journal of Knowledge Management Studies, 11(1):

59-80. https://www.inderscienceonline.com/doi/abs/10.1504/IJKMS.2020.105073 
Nurhayati, Sri and Wasilah Wasilah. 2015. Akuntansi Syariah di Indonesia. Jakarta: Salemba Empat.

Oktaviani, Novi. 2018. Pengaruh Religiusitas, Pengetahuan Dan Lokasi Terhadap Minat Menabung Pada Bank Syariah Dengan Kepercayaan Sebagai Variabel Intervening (Studi Kasus Pada Masyarakat di Blotongan Kota Salatiga). Skripsi Institut Agama Islam Negeri (IAIN) Salatiga. http://e-repository.perpus.iainsalatiga.ac.id/4757/.

Pebrianto, Fajar. 2021. Penetrasi Perbankan Syariah RI 6,51 Persen, Malaysia Sudah 29 Persen. https://bisnis.tempo.co/read/1443030/penetrasiperbankan-syariah-ri-651-persen-malaysia-sudah-29-persen.

Pradesyah, Riyan. 2020. "Pengaruh Promosi Dan Pengetahuan Terhadap Minat Masyarakat Melakukan Transaksi Di Bank Syariah (Studi Kasus Di Desa Rahuning)." Al-Sharf: Jurnal Ekonomi Islam, 1(2): 113-122. http://ejurnalilmiah.com/index.php/Mudharib/article/view/65.

Prihanto, Hendi. 2017. "Analisis Terhadap Faktor-Faktor Yang Memengaruhi Masyarakat Untuk Menabung Di Bank Syariah.” Profita: Komunikasi Ilmiah Akuntansi dan Perpajakan, 10(1): 1-26. https://publikasi.mercubuana.ac.id/index.php/profita/article/view/2892.

Rismawati, Fitria, Sri Wahyuni, and Joko Widodo. 2019. "Strategi Pemasaran STP (Segmenting, Targeting, Positioning) Larissa Aesthetic Center Cabang Jember." Jurnal Pendidikan Ekonomi: Jurnal Ilmiah Ilmu Pendidikan, Ilmu Ekonomi Dan Ilmu Sosial 13 (2): 68-72. https://doi.org/10.19184/jpe.v13i2.10793.

Sholihin Mahfud, and Dwi Ratmono. 2021. Analisis SEM-PLS dengan WarpPLS 7.0 untuk Hubungan Nonlinier dalam Penelitian Sosial dan Bisnis. Yogyakarta: Andi.

Sriwahyuni, Endang. 2019. Pengaruh Lokasi dan Kualitas Pelayanan Terhadap Keputusan Nasabah Menabung di Bank Syariah (Studi Pada Bank BRI Syariah KCP Ngawi). Skripsi Institut Agama Islam Negeri (IAIN) Ponorogo. http://etheses.iainponorogo.ac.id/8157/.

Syaputra, A. D. 2017. "Hubungan Sistem bagi Hasil di Lembaga Keuangan Syari'ah dengan Keinginan Nasabah untuk Berinvestasi Di BPR Syariah Bangun Drajat Warga Yogyakarta." Islamadina: Jurnal Pemikiran Islam, 18(2), 21-40.

Syarif, Muhammad Mufti. (2019). Pengaruh Promosi, Kualitas Pelayanan, dan Lokasi Terhadap Minat Menabung Dengan Pengetahuan Keunggulan Produk Sebagai Variabel Intervening (Studi Kasus Pada BRI Syariah KC. Semarang). Skripsi Institut Agama Islam Negeri (IAIN) Salatiga. http://erepository.perpus.iainsalatiga.ac.id/5307/.

Tjiptono, Fandy. 2009. Manajemen Jasa, cetakan kedua, edisi kesatu. Jakarta: Erlangga.

Tripuspitorini, Fifi Afiyanti. 2020. "Pengaruh Religiusitas Terhadap Minat Mahasiswa Politeknik Negeri Bandung Untuk Menabung Di Bank Syariah." Masharif al-Syariah: Jurnal Ekonomi dan Perbankan Syariah, 4(2): $\quad$ 54-69. http://journal.umsurabaya.ac.id/index.php/Mas/article/view/2636.

Untoro, Dzaky Fauzan. 2020. Pengaruh Faktor Promosi, Kepercayaan, Pendapatan dan Lokasi Terhadap Minat Masyarakat Menabung di Bank 
Syariah (Studi Kasus di Wilayah Tangerang Raya). Skripsi UIN Syarif Hidayatullah Jakarta. https://repository.uinjkt.ac.id/dspace/handle/123456789/51400.

Wahab, Wirdayani. 2016. "Pengaruh Bagi Hasil Terhadap Minat Menabung di Bank Syariah." Jurnal Eknomi dan Bisnis Islam,1(2): 167-184. http://journal.febi.uinib.ac.id/index.php/jebi/article/view/33.

Wahjono, Sentot Imam. 2010. Manajemen Pemasaran Bank. Yogyakarta: Graha Ilmu.

Wasilah and Sri Nurhayati, 2013. Akutansi Syariah di Indonesia. Jakarta: Salemba Empat.

Wilardjo. Setia Budhi. 2005. "Pengertian, Peranan Dan Perkembangan Bank Syari'ah Di Indonesia." Value Added: Majalah Ekonomi dan Bisnis, 2(1): 1-10. https://jurnal.unimus.ac.id/index.php/vadded/article/view/654/.

Yudiana, Fetria Eka. 2014. Manajemen Pembiayaan Bank Syariah. Salatiga: STAIN Salatiga Press. 